\title{
Erratum zu: Perspektiven von Journalismus auf YouTube
}

Michael Frenzel

\section{Erratum zu: \\ Kapitel ,Perspektiven von Journalismus auf YouTube“ in: H. Haarkötter und J. Wergen (Hrsg.), Das YouTubiversum, https://doi.org/10.1007/978-3-658-22846-0_7}

Auf den S.122 bzw. 123 (Tabelle) wurde der letzte Stand der Finanzierung des Crowd-Journalismus Projektes Crowdspondent von Lisa Altmeier und Stefanie Fetz nicht korrekt wiedergegeben. Diese Textstellen wurden nun durch die richtigen Angaben ersetzt. 